\title{
MARXISMO E FILOSOFIA: ALGUMAS CONSIDERAÇÕES SOBRE OS TEXTOS POLITICOS MERLEAU-PONTYANOS DO PÓS-GUERRA*
}

\author{
Cristina Diniz MENDONÇA**
}

\begin{abstract}
RESUMO: A tentativa merleau-pontyana de aproximação do marxismo, empreendida nos idos do pós-guerra, é perpassada por constante ambigüidade. Não obstante o propósito do filósofo de se filiar à teoria de Marx, suas análises politicas revelam-se distantes de suas intençōes. Concebendo a história como uma "aventura" que escapa a qualquer esquema racional, Merleau-Ponty questiona, desde seus primeiros escritos, a dialética marxista entre Iogica e contingéncia na história. A tensão interna que dilacera os textos do autor nos anos 40, anunciando (e preparando) a recusa da teoria da revolução estampada mais tarde nas Aventuras da Dialética, permite indagar se esse desfecho dos anos 50 não teria sido, ao invés de um corte no interior da obra, o resultado necessário dessa tentativa problemática de aproximação do marxismo a partir de categorias que Ihe são estranhas (próprias às filosofias da existência e à fenomenologia).
\end{abstract}

UNITERMOS: Marxismo; existencialismo; attentisme marxiste; teoria da história; Iógica e contingência na história; revolução; "liberalismo heróico" weberiano.

Com um passado filosófico que remonta ao pré-guerra, enraizado na fenomenologia alemã e herdeiro da leitura kojèveana de Hegel, Merleau-Ponty inicia a segunda metade dos anos 40 seu diálogo com o marxismo. Partindo de uma interpretação "existencialista" de Marx, o filósofo se lança, naqueles idos do pós-guerra, numa tentativa de pensar a história e a política vinculando-as às articulações da existência. Sugestivamente, o texto de abertura de Sens et Non-Sens - livro onde o autor reúne, entre outras, algumas de suas reflexões sobre a história e a política - é uma meditação sobre Cézanne. A arte aparece sempre como o pano de fundo do pensamento merleau-pontyano sobre a história. Para além das transformações ocorridas na trajetória do filósofo, permanece constante em seus textos a idéia de que cada momento histórico, como uma obra de arte encerra em si uma existência singular e, nessa medida, precisa ser compreendido na sua particularidade e não à luz de uma suposta lógica imanente ao curso da História. O problema das relações entre o particular e o universal, a contingência e a necessidade históricas, constituiu, desde seus primeiros textos, o centro das desconfianças de MerleauPonty a respeito do marxismo.

Os caminhos da Revolução Russa e a não internacionalização do processo revolucio-

* Este texto contitui parte do segundo capítulo de nossa dissertação de Mestrado - Merleau-Ponty: Marxismo e Filosofia - apresentada ao Departamento de Filosofia da Faculdade de Filosofia, Letras e Ciências Humanas da Universidade de São Paulo.

** Departamento de Filosofia - Faculdade de Educação, Filosofia, Ciências Sociais e da Documentação - UNESP - 17500 - Marilia - SP. 
nário significaram, para nosso autor, o questionamento das linhas mestras traçadas pela teoria marxista da história. Conforme afirma em Sens et Non-Sens, a contingência "baralhou"' a lógica da história concebida pelo marxismo. Após a experiência de 1917, Merleau-Ponty acredita que não é mais possivel apostar na racionalidade da história. Ao invés da realização da razão, o que ocorreu foi o advento de uma crise histórica ou, na expressão do filósofo, o "descarrilamento" trágico da história e da dialética.

Quais as lições dessa crise? Desde a época de Sens et Non-Sens e Humanisme et Terreur - período em que mais procurou se aproximar do marxismo - até os seus últimos escritos, a resposta de Merleau-Ponty, nesse particular, não mudou significativamente: é preciso compreender que a contingência e a ambigüidade estão no coração da história. Às vezes nas entrelinhas, outras vezes claramente tematizada, a idéia de uma história ambigua, caprichosa, dissimulada e não transparente à razão perpassa toda a obra merleaupontyana. A história é sempre apresentada pelo filósofo como o lugar do mistério e do equívoco - ela só se torna verdadeiramente inteligivel em alguns raros momentos privilegiados. A experiência dos últimos anos exige, segundo Merleau-Ponty, uma reflexão sobre a presença do não-senso na história. Os rumos da revolução tornaram evidente que o não-senso é parte constitutiva do processo histórico e mostraram, de maneira decisiva, o aspecto absurdo da história.

Concebida como "fulguração da existência", a história significa para Merleau-Ponty o domínio da indeterminação: é uma "aventura" que escapa a qualquer esquema racional. Procurando colocar o indivíduo, a liberdade e a consciência no centro da história, o objetivo do autor é fazer a crítica das noções de necessidade e de finalidade históricas. Se a existência humana é indeterminada - e a história é a ilustração da existência - como sustentar que a revolução está inscrita, ainda que como possibilidade, no curso do processo histórico? Embora de maneira implícita, esta questão atravessa toda a obra de Merleau-Ponty, norteando suas reflexões sobre a história. O que o filósofo põe em dúvida, desde o início, é a teoria que vislumbra a revolução no fim do caminho percorrido. Dai sua constante reserva frente ao marxismo.

Nos anos que se seguiram à Libertação - e mesmo nos textos considerados mais tarde por Merleau-Ponty como a expressão de um momento de esperança (Nota a) - já está presente no pensamento merleau-pontyano uma visão pessimista do processo histórico que, em filigrana, vai tecendo uma atitude cética a respeito da teoria marxista da história e da revolução.

É assim que no ensaio "Autour du Marxisme" (agosto de 1945) encontramos MerleauPonty profundamente hesitante face à teoria de Marx. O objetivo do texto, no entanto, é fazer a defesa do marxismo contra as críticas que Thierry Maulnier lhe endereçara (Nota b) - "Havia muita injustiça - escreve o filósofo - na censura que Thierry Maulnier dirigia ao marxismo entendido como um materialismo abstrato". A crítica de certas fórmulas marxistas que permitem "equívocos mecanicistas", acrescenta o autor, "não nos autoriza a transcender ou 'ultrapassar' a análise econômica, nem a abandonar o fio condutor da luta de classes" (6, p. 190). Esta afirmação, entretanto, será inteiramente desfeita no interior do próprio texto de Merleau-Ponty.

Ao longo do ensaio, a análise merleau-pontyana oscila: ora procura colocar o marxismo a salvo das críticas a ele endereçadas, ora reconhece que essas críticas têm razão de ser. O curioso é que tal oscilação vai sendo resolvida (embora não chegue a se resolvercompletamente) conforme Merleau-Ponty vai fazendo suas as reservas de Maulnier a respeito do marxismo. Nesse sentido, o filósofo escreve: “Não há, pois, qualquer fundamento para as hesitações de Thierry Maulnier diante do marxismo? Pelo contrário, pensamos que, desembaraçadas de seus motivos "reacionários", tais hesitações têm uma significação profunda e formulamos a crítica precedente justamente para destacar o que chamaremos de: o problema marxista em sua pureza" (6, p. 209). Merleau-Ponty critica a veemência das acusações de Maulnier à teoria marxista, mas, ao mesmo tempo, incorpora suas hesitações diante desta teoria.

Trans/Form/Ação, São Paulo, 9/10: 21-39, 1986/87. 
Qual seria, então, esse "problema" inerente ao marxismo que, segundo MerleauPonty, justificaria as desconfianças de Maulnier? A análise merleau-pontyana procura mostrar que o marxismo encerra uma "dificuldade interna": a dialética entre lógica e contingência na história. O mérito do livro de Maulnier estaria, nessa medida, em ter apontado um problema real capaz de questionar a teoria de Marx.

Merleau-Ponty considera que a presença da contingência na história denuncia a fragilidade do marxismo. "A contingência, escreve o filósofo, significa que a dialética da história pode enterrar-se ou desviar-se em aventuras, sem resolver os problemas que pôs a nu" (6, p. 213). O ponto de vista de nosso autor coincide, agora, com o de Maulnier: "Parece-nos que, para além de seus preconceitos, a verdade de seu livro reside na percepção clara de que há na história, como diz Jean Hyppolite, "fatos dialéticos", embora não consiga aderir à idéia de uma dialética única da história" (6, p. 210-211). MerleauPonty também não pode aderir a tal idéia - donde a importância que outorga às análises de Maulnier.

Indicando a necessidade de abandonar a "idéia teológica de um fundo racional do mundo", Merleau-Ponty formula a hipótese de que o processo histórico não seria senão uma "série de diversões", um "mundo de acidentes" sem garantia de um desenvolvimento lógico (6, p. 213). Nessa perspectiva, "a história não seria mais um discurso com uma seqüência determinada e cujo acabamento poderia ser esperado com segurança. Não mais um discurso onde cada frase teria seu lugar necessário, mas, como palavras de um bêbado, discurso que indicaria uma idéia que logo se apagaria para reaparecer em seguida e voltar a desaparecer ainda uma vez, sem chegar necessariamente à sua expressão plena" (6, p. 213-214). Compreendida segundo analogia com a linguagem, a história é pois apresentada por Merleau-Ponty como um discurso. E mais: tratar-se-ia, conforme a hipótese do filósofo, de um discurso truncado - "palavras de um bêbado". A história não seria portanto um "raciocínio seqüente", como afirmará Merleau-Ponty, mais tarde, comentando Weber (Nota c). Ao invés de uma determinação constante, haveria na história clarões de inteligibilidade, momentos de lampejos que fazem sentido. Momentos efêmeros, é verdade, que iluminariam rapidamente a cena e logo se apagariam novamente - fulgurações na escuridão da história. Nessa medida, o processo histórico não seria inteligível na sua totalidade. Haveria, pois, uma opacidade da história da mesma forma que o filósofo afirma haver uma "opacidade da linguagem" (9, p. 333). "Em vez de um mundo inteligível" - escreve Merleau-Ponty no prefácio de Sens et Non-Sens, de maneira, agora, muito mais afirmativa - "existem núcleos irradiantes separados por nesgas de noites (pans de nuits)" (6, p. 8). Compreendemos então que, de acordo com essa concepção merleau-pontyana, a história, como uma tela de Cézanne, permite-nos captar instantes, flashes do mundo, mas, misteriosa, não se revela totalmente à razão (Nota d).

À medida que, no diálogo com Maulnier, Merleau-Ponty delineia suas reflexões sobre a história, sua defesa do marxismo vai-se revelando mais e mais frágil, acanhada quase. Pensando a história como um conjunto de acidentes, o filósofo pretende mostrar a impossibilidade de um conhecimento real de seus caminhos e de seus resultados. A experiência da Revolução Russa, "embaralhando os esquemas do marxismo" (6, p. 215), mostrou, segundo Merleau-Ponty, que a contingência prepondera sobre a lógica na história. Em vez da dialética entre necessidade e contingência históricas, nosso autor prefere falar num "jogo" dos acontecimentos na história (6, p. 212). Dada a presença da contingência no processo histórico, "acabar-se-á concluindo", escreve Merleau-Ponty, "que a lógica e a história se divorciam de sorte que a história empírica nunca realiza aquilo que nos parece ser a seqüência da história" $(6,212)$. Se a história é o domínio das incertezas, é preciso então questionar a noção de finalidade histórica: "A história comporta vetores", afirma ainda o autor, mas isso não significa que "nela as coisas se disponham em vista de um fim" (6, p. 184). O corolário dessas reflexões decorre, pois, necessariamente: "ora, perdendo o caráter de um porvir necessário, a revolução não cessa de ser a dimensão

Trans/Form/Ação, São Paulo, 9/10: 21-39, 1986/87. 
fundamental da história? E, com relação à história efetiva, que no final das contas é a única que importa, aquele que julga todas as coisas pelo ângulo da luta de classes não opera com uma perspectiva arbitrária?" (6, p. 212). Ao invés da pretendida defesa do marxismo, encontramos aqui, portanto, o questionamento da teoria marxista da história e da revolução.

Merleau-Ponty procura resolver a ambigüidade que perpassa sua análise tentando, em algumas passagens, aproximar a teoria marxista do ponto de vista de uma "teoria existencial da história" (Nota e). "Reconduzido ao essencial", afirma o autor, "o marxismo não é uma filosofia otimista - é somente a idéia de que uma outra história é possível, que não há destino e que a existência do homem é aberta. E a tentativa resoluta por esse futuro que ninguém no mundo, nem fora do mundo, sabe se será ou não será" $(6, p$. 209). Nessa perspectiva, o marxismo poderia ser a teoria capaz de inscrever a contingência no centro da história. Donde o esforço que Merleau-Ponty empreende no sentido de vincular a noção de lógica da história à idéia de drama. Descrevendo a história como um drama onde os acontecimentos têm uma "significação humana", a análise do filósofo aos poucos vai diluindo, justamente, a idéia de uma necessidade imanente ao curso do processo histórico. Se não há um "fundo racional do mundo", escreve Merleau-Ponty, "a lógica da história torna-se apenas uma possibilidade entre outras" (6, p. 213). Já está presente nas entrelinhas das reflexões do autor a recusa - explicitada mais tarde - da idéia de que a dialética é a forma de um processo objetivo.

Não obstante Merleau-Ponty pretenda salvar a teoria de Marx das críticas que Maulnier lhe dirigira, o problema da dialética entre a necessidade e a contingência na história evidencia, a cada momento, a dificuldade da relação do filósofo com aquela teoria. Finalmente, o problema é reaberto de tal maneira que não pode mais ser contornado: "Se quisermos aplicar a análise marxista aos acontecimentos que preenchem nosso tempo, tal análise se perde nos fenômenos transversais, nas reações inesperadas, correndo atrás dos acontecimentos sem conseguir alcançá-los, e, em todo caso, sem nunca antecedêlos. Um marxista lúcido, vendo como o esquema da luta de classes se diversifica e matiza, acaba se perguntando se, de diversão em diversão, a história será, finalmente, a história da luta de classes e se não está sonhando de olhos abertos" (6, p. 217). A afirmação inicial de que não se pode "abandonar o fio condutor da luta de classes" foi, portanto, desmontada ao longo das reflexões de Merleau-Ponty. Embora o filósofo ainda não dê uma resposta clara para as questões que formula sobre a verdade da teoria marxista da história, ele tampouco pode sustentar uma defesa do marxismo. O tom de seu ensaio é sobretudo interrogativo. Essas interrogações, no entanto, preparam as respostas que encontraremos, mais tarde, em Les Aventures de la Dialectique. Por enquanto,ainda em dúvida se a concepção marxista da história será validada pela própria história, MerleauPonty formula aquilo que denominará posteriormente de "atitude de temporização marxista" (attentisme marxiste) (Nota f): "Se amanhã, como é possível, e mesmo provável após uma guerra, a luta de classes reaparecer e acusar-se em todos os países do mundo, de novo as grandes linhas marxistas da história aparecerão" (6, p. 217). Em compasso de espera, nosso autor coloca a teoria marxista da história entre parênteses.

Em meio às dúvidas e interrogações daquele momento, uma certeza, no entanto, permeia o ensaio "Autour du Marxisme": atualmente, a luta de classes não é mais o motor da história. Pode voltar a sê-lo, mas, de fato, hoje ela não se faz presente. Mesmo afirmando, contra Maulnier, que não se pode deixar de lado a perspectiva da luta de classes, a análise merleau-pontyana não se direciona por essa perspectiva. Ela surge no interior do texto do filósofo como algo que ainda pode, talvez, suscitar esperanças de transformação social, mas não é constitutiva de sua análise. Pelo contrário, em nome da contingência e das situações históricas particulares, Merleau-Ponty vai mesmo questionar a idéia de luta de classes como "princípio geral da história": "Contudo, perguntamos se a política eficaz para um dado país não consistiria em tentar, bem ou mal, dar a si próprio um lugar neste mundo de acidentes tal como é, em vez de ordenar toda sua conduta pela

Trans/Form/Ação, São Paulo, 9/10: 21-39, 1986/87. 
relação que deve manter com a luta de classes, princípio geral da história. Não há mais sentido em tratar a luta de classes como um fato essencial se não estivermos seguros de que a história efetiva permanece fiel à sua "essência", e de que os acidentes não tecem sua trama durante longo tempo ou, mesmo, para sempre" (6, p. 213, Nota g). Embora nesse momento o filósofo ainda considere a possibilidade de um "reaparecimento" da luta de classes que a confirme como um "fato essencial" da história, o prenúncio de seu rompimento definitivo com o marxismo já pode ser aqui percebido.

No final do texto, encontramos a seguinte hipótese: "O proletariado universal, pesando em todas as partes do aparelho capitalista, destruindo-o para substituí-lo por uma civilização socialista, não seria um fato, mas um voto, não uma força existente sobre a qual poderemos nos apoiar, mas uma força a ser criada, visto que, de fato, os proletariados nacionais podem ser seduzidos pelas "diversões" da história" (6, p. 214). Considerando que as "diversões" da história questionaram o esquema marxista original, MerleauPonty já indica a necessidade de "prolongar e renovar" certas análises de Marx (6, p. 207). Não por acaso, na última nota do ensaio, o filósofo refere-se à importância de "prolongar no plano teórico as conclusões práticas" adotadas por Lenin: "Poder-se-ia retirar uma teoria da contingência da história de sua "percepção" marxista das situações" (6, p. 217). Se num primeiro momento Merleau-Ponty tentou encontrar no marxismo essa "teoria da contingência da história", mais tarde, no entanto, acreditamos que vai buscá-la em Weber, recusando definitivamente a perspectiva marxista da dialética entre necessidade e contingência históricas.

O espírito do periodo de attentisme marxiste pode ser sintetizado numa passagem de Merleau-Ponty em "Pour la Vérité" (novembro de 1945) que confirma as idéias centrais do texto anterior: "Não afirmamos que a luta de classes não desempenhará nunca mais um papel essencial na história mundial. Não sabemos nada a esse respeito (...). Afirmamos apenas que, no momento, ela está mascarada e latente (...)" (6, p. 302). A perplexidade face aos caminhos traçados pela história suspende as certezas e leva Merleau-Ponty a reiterar, de certa maneira, a tese já apresentada na Phénoménologie de la Perception: a ambigüidade da história torna o conhecimento histórico também ambíguo (10, p. 201). Em "Pour la Vérité" o argumento é fundamentalmente o mesmo de "Autour du Marxisme": a história, contrariando a perspectiva marxista, não respondeu ao apelo da razão, ensinando que suas vias "são insondáveis" e que o caminho por ela percorrido é sem garantia. O filósofo procura reafirmar a idéia de que a contingência e a ambigüidade estão inscritas no curso da história ininterruptamente.

O momento histórico presente, acentua Merleau-Ponty, é equívoco e nele não podemos reconhecer o eixo central do esquema marxista clássico. A luta de classes, tal como foi descrita por Marx, não tem lugar: está paralisada. O que se evidencia hoje, contrariamente à internacionalização do processo revolucionário, é uma situação de refluxo expressa pelo enfraquecimento histórico do proletariado. Embora essa constatação se faça na linha direta de "Autour du Marxisme", o filósofo já avança agora algumas conclusões. Visto que os acasos sobrepujaram os fatores considerados essenciais do desenvolvimento histórico, afirma o autor, estamos hoje mais próximos do advento da barbárie do que do advento da humanidade. Um sintoma disso pode ser detectado: "O proletariado como classe está demasiadamente enfraquecido para permanecer no presente um fator autônomo da história" (6, p. 288). Daí o diagnóstico de um "descarrilamento da história" que põe o marxismo em questão: "Os fatores nacionais, geográficos e psicológicos que se cruzam com a luta de classes embaralham as grandes linhas marxistas da história" (6, p. 288, Nota h).

Merleau-Ponty procura mostrar que a indeterminação do processo histórico, a opacidade da prática social, enfim, o "equívoco perpétuo da história" (6, p. 292), colocam dificuldades não resolvidas pelo marxismo e justificam a necessidade de uma "leitura do presente" (6, p. 299). Partindo de cada situação particular, e não do esquema geral da luta de classes, essa "leitura do presente" deve levar em conta o senso e o não-senso na his-

Trans/Form/Ação, São Paulo, 9/10: 21-39, 1986/87. 
tória e, sobretudo, refletir sobre a atualidade da concepção marxista da história. O filósofo já está considerando a possibilidade de se apagarem definitivamente as linhas mestras da história tais como o marxismo as traçou. Nessa medida, ainda que como hipótese, a recusa do marxismo como teoria da história e da revolução está portanto esboçada nas reflexões merleau-pontyanas do pós-guerra. No final de "Pour la Vérité" encontramos explicitada a questão que, embora não respondida naquele momento, direcionou o ensaio: "Podemos saber se há ainda uma dialética e se a história, finalmente, será racional?" (6, p. 303). Alguns anos mais tarde, no artigo "La Politique Paranoïaque" (julho de 1948), Merleau-Ponty, atendo-se ainda às interrogações, delimita melhor a questão: o momento da explosão revolucionária de 1917 teria, naquele instante, confirmado a lógica da história descrita pelo marxismo ou, pelo contrário, teria sido um "caso privilegiado excepcionalmente favorável à concepção marxista da história"? (8, p. 327).

É, sem dúvida, em Humanisme et Terreur (Nota i) que as incertezas e interrogações próprias ao periodo de attentisme marxiste transparecem de maneira decisiva. Expressão maior do pensamento político do filósofo nos anos 40 , este livro nos permite acompanhar mais de perto os meandros do diálogo merleau-pontyano com o marxismo, suas oscilações e ambigüidades. Retomando e levando adiante as análises de Sens et NonSens, Merleau-Ponty pretende agora, a partir de uma reflexão sobre o romance de Arthur Koestler, Darkness at Noon, dar conta de uma situação histórica concreta: os processos de Moscou.

Afirmando que o livro de Koestler "coloca o problema de nosso tempo mas não o faz como deve" (7, p. 84), Merleau-Ponty procura mostrar que o autor "é estranho ao marxismo", ou melhor, trata-se de um "marxista medíocre". E, exatamente por não entender o verdadeiro sentido do marxismo, Koestler tampouco pode entender o verdadeiro sentido dos processos de Moscou. Ao longo de Humanisme et Terreur vamos percebendo porque "há bem pouco marxismo em Le Zero et l'Infini": Koestler não teria compreendido a "idéia de uma história dialética", estando, pois, distante da "lógica viva da história descrita por Marx" (7, p. 97, 99, 104 e 108). O alvo das críticas de nosso autor é a degradação a que o "cientificismo sociológico" - do qual Koestler é legítimo representante - condenou a teoria de Marx e cujo resultado é uma dialectique brisée (7, p. 254). Contra tal degradação, o filósofo pretende recuperar o "bom método marxista" (7, p. 134) para poder desvendar o "segredo" dos processos de Moscou. É justamente essa tentativa de recuperação do marxismo e da dialética que, conforme acreditamos, determina a ambigüidade que atravessa Humanisme et Terreur. Merleau-Ponty se propõe a falar em nome da teoria marxista, mas sua análise, no entanto, revela-se distante de suas intenções.

O objetivo do livro é perfeitamente definido na resposta que Merleau-Ponty endereça àqueles que o criticaram: "... retomamos a questão da violência comunista que Le Zéro et l'infinit de Koestler punha na ordem do dia. Não averiguamos se Boukharin dirigia verdadeiramente uma oposição organizada, nem se a execução dos velhos bolchevistas era verdadeiramente indispensável à ordem e à defesa nacional da U. R. S. S. Nosso propósito não era refazer os processos de 1937. Era compreender Boukharin como Koestler procura compreender Roubachof, pois o caso Boukharin põe em evidência a teoria e a prática da violência no comunismo, na medida em que ele a exerce sobre si mesmo e motiva sua própria condenação. Procuramos reencontrar, sob as convenções de linguagem, o que Bukharin verdadeiramente pensava. A explicação de Koestler pareceu-nos insuficiente" (7, p. 41-42; os grifos são nossos). Esta passagem expõe as linhas gerais da análise merleaupontyana dos processos de Moscou: trata-se de "compreender Bukharin" como Koestler procurou compreender o personagem de seu romance, ou seja, tentando decifrar seu verdadeiro pensamento "sob as convenções de linguagem". Deixando de lado a história social e política da qual Bukharin fazia parte, Merleau-Ponty se propõe a examinar seu discurso tal como foi transcrito em L'Acte d'Accusation, Compte rendu sténographique des Débats. O leitor de Humanisme et Terreur pode perceber então, desde o início, a grande 
dificuldade do propósito merleau-pontyano: embora pretenda fazer uma análise marxista dos processos de Moscou, Merleau-Ponty apaga, justamente, como bem observou Lefort, seu "contexto sócio-histórico" (Nota j).

Com efeito, em Humanisme et Terreur os processos de Moscou são descritos, na expressão do próprio Merleau-Ponty, como uma "cerimônia de linguagem" (7, p. 113). Limitando-se ao exame do debate entre Bukharin e Vichynski, Merleau-Ponty define os processos como sendo "de forma e de estilo revolucionários" (7, p. 114). O conteúdo dos processos - os fatos históricos que determinaram a aniquilação pura e simples de quase toda a geração de 1917 - não é jamais considerado. Buscando o sentido que se oculta sob a linguagem manifesta dos debates, a análise merleau-pontyana procura ressaltar o aspecto subjetivo dos processos de Moscou: trata-se de mostrar o drama do homem dilacerado entre suas intenções e o resultados de seus atos - "o drama da responsabilidade histórica" (7, p. 167). Nessa medida, o autor pode afirmar que "os processos permanecem no subjetivo" (7, p. 114) e só podem ser compreendidos "entre homens convencidos de fazer a história" (7, p. 115-116).

O objetivo do livro é ainda uma vez explicitado: "não pretendemos polemizar: limitamo-nos a enunciar o que podiam ser os processos de Moscou nas condições em que estavam constituidos" (7, p. 113). Quais condições? Ao procurarmos a resposta nas páginas de Humanisme et Terreur encontraremos, surpreendentemente, em vez de uma análise da situação histórica concreta da sociedade soviética, uma longa reflexão sobre a história recente da França: a Guerra, a Ocupação e a Resistência. A experiência da Resistência e os processos dos colaboradores são rememorados para iluminar os processos de Moscou. Nas palavras de Merleau-Ponty: "A experiência da guerra pode nos ajudar a compreender os dilemas de Roubachof e os processos de Moscou" (7, p. 133). Ou então: "Procuramos compreender Boukharin ( ... ) transportando-nos à nossa recente experiência" ( 7, p. 43). E ainda: "Como os processos dos colaboradores desinteressados, os processos de Moscou seriam o drama da honestidade subjetiva e da traição objetiva" (7, p. 133). Tomando, pois, a Guerra e a Resistência como pano de fundo histórico de suas reflexões, Merleau-Ponty coloca o problema das relações entre subjetividade e objetividade na história.

Não podemos nos esquecer que a Resistência significou para Merleau-Ponty um momento privilegiado no qual a história se tornou inteligivel, ou melhor, as relações entre o individuo e a história se tornaram transparentes. Tratava-se de um momento em que a história foi posta "em suspenso", exigindo do homem "decisões fundamentais" (7, p. 43). Já em "La Guerre a eu lieu" (1945) nosso autor exaltara a Resistência como uma ação histórica que era também pessoal e determinada quase que exclusivamente pelos "elementos psicológicos e morais da política" (6, p. 266). Naquela situação histórica limite, afirma Merleau-Ponty, naquele momento de pura negação, o indivíduo ocupou o centro da história e a política era uma "relação de consciência a consciência", de "homem a homem". O resistente colocou na ordem do dia a busca da liberdade e das "relações transparentes entre os homens". A Resistência, acrescenta o autor, foi a experiência da "felicidade em meio ao perigo" (6, p. 266, 267 e 268). O filósofo procura, pois, descrevê-la como uma "aventura" ao mesmo tempo individual e histórica - uma espécie de heroísmo da consciência num momento político decisivo. Com efeito, podemos encontrar nas análises merleau-pontyanas o resistente vinculado à figura do herói: "Os resistentes não são loucos nem sábios, são heróis" (7, p. 130, Nota k). Neste ponto, a analogia com os processos de Moscou torna-se mais clara: Bukharin, como o resistente, é o herói chamado a uma "decisão fundamental" (Nota I).

Através de Humanisme et Terreur pode-se perceber que o "trágico" da política surge justamente quando, no momento oportuno, é preciso decidir qual é a melhor escolha. "Quem leu melhor a história?" (7, p. 160) - pergunta Merleau-Ponty. Ou então: "Forçados a escolher entre o respeito das consciências e a ação, (...) nossa escolha não é sempre boa e sempre má?" (7, p. 68-69). Nessa medida, o homem político vive "o pesadelo de 
uma responsabilidade involuntária e de uma culpabilidade em si que sustentava já o mito de Édipo: Édipo não quis esposar sua mãe nem matar seu pai, mas ele o fez e o fato vale como crime ( ... ). A consciência desse conflito da história humana está no seu mais alto ponto na sociologia de Marx Weber" (7, p. 69-70). Este é o único momento do livro em que o autor, utilizando-se do estudo de Raymond Aron, La Sociologie Allemande Contemporaine, faz referência explícita a Weber. Entretanto, é possível reconhecer traços das análises de Weber na própria interpretação merleau-pontyana dos processos de Moscou como o "drama da honestidade subjetiva e da traição objetiva". Nesse sentido, caberia lembrar aqui apenas uma passagem de Aron (cujo livro é justamente a fonte da leitura de Weber feita por Merleau-Ponty): "O caso do protestantismo é privilegiado (por Weber) porque permite apreender o caráter dramático da história: o paradoxo das conseqüências que contradizem a intenção dos homens" (1, p. 116). Mas não é esse, exatamente, o eixo da análise dos processos de Moscou feita por Merleau-Ponty? Em Les Aventures de la Dialectique o pensamento weberiano será apresentado como um "liberalismo sofredor, heróico" (11, p. 42). No ensaio "Autour du Marxisme", o autor afirmava que o verdadeiro marxismo admite uma "moral heróica que prescreve aos homens pôr em jogo suas próprias vidas" (6, p. 189). Agora, em Humanisme et Terreur, o homem político é o herói que, devido a uma "escolha fundamental", desafia as "forças exteriores" - ele é um personagem do "drama da responsabilidade histórica".

O livro de Koestler representa para Merleau-Ponty justamente a oportunidade de retomar esse problema - já colocado na ordem do dia pela Resistência - das relações entre o indivíduo e a política. É assim que podemos ler em Humanisme et Terreur: "Os próprios erros de Koestler na sua formulação dos problemas nos conduzem às seguintes questões: Há de fato uma alternativa da eficácia e do humano, da ação histórica e da moralidade? (...) É verdade, conforme a famosa frase de Napoleão, que a política é a moderna tragédia onde se enfrentam a verdade do indivíduo e as exigências da generalidade, como, na tragédia antiga, a vontade do herói e o destino fixado pelos deuses?" (7, p. 108-109, Nota m). A resposta para essas questões não é formulada explicitamente, mas é indicada na própria interpretação merleau-pontyana dos processos: "Há pois um drama dos processos de Moscou, mas do qual Koestler está longe de dar a verdadeira fórmula. (...) A tragédia começa quando o mesmo homem compreendeu ao mesmo tempo que ele não poderia negar a figura objetiva de suas ações, que ele é o que é para os outros no contexto da história e que, entretanto, o motivo de sua ação continua sendo o valor do homem tal qual ele o sente imediatamente" (7, p. 155-156). Colocando solenemente o conflito no coração do homem (tomado genericamente), Merleau-Ponty, que pretendera justamente falar em nome das sittuações históricas particulares, põe de lado a especificidade dos processos de Moscou, descaracterizando-os: "Toda a tragédia grega subentende esta idéia de um acaso fundamental que nos faz todos culpados e todos inocentes porque não sabemos o que fazemos. Hegel exprimiu admiravelmente a imparcialidade do herói que vê que os seus adversários não são necessariamente "maus", que em um sentido todo o mundo tem razão e cumpre a sua tarefa sem esperar ser aprovado por todos nem inteiramente por si próprio" (7, p. 69-70). Na "tragédia" do homem que se vê constantemente "às voltas com as forças exteriores das quais ele é secretamente cúmplice", o autor sintetiza, finalmente, sua interpretação dos processos de Moscou: "A divisão não é mais entre o homem e o mundo, mas entre o homem e ele próprio. Eis todo o segredo das confissões de Moscou" (7, p. 160). "Segredo" que, como assinalamos, o filósofo procurou desvelar atendo-se à "cerimônia de linguagem" dos debates e a partir da experiência histórica da Resistência.

No entanto, isso não encerra senão uma meia-verdade sobre a análise merleau-pontyana dos processos de Moscou. Insinuando-se nas reflexões do filósofo e determinando sua direção, reencontramos em Humanisme et Terreur o problema central dos ensaios de Sens et Non-Sens: a relação entre a lógica e a contingência na história. É assim que ao longo do paralelo estabelecido pelo autor entre a Resistência e os processos de Moscou, po-

Trans/Form/Ação, São Paulo, 9/10: 21-39, 1986/87. 
demos ler o seguinte: "A glória dos resistentes assim como a indignidade dos colaboradores supõe, ao mesmo tempo, a contingência da história, sem a qual não há culpados em política, e a racionalidade da história, sem a qual só existem loucos" (7, p. 130). Merleau-Ponty designa como "paradoxo da história" (7, p. 132) o fato dela ser ao mesmo tempo necessária e contingente. Todavia, a análise merleau-pontyana sugere que o equilíbrio entre esses dois aspectos da história é instável e que a contingência acaba prevalecendo sobre a necessidade histórica. E é aqui que reside o sentido profundo do drama dos processos de Moscou: "No processo de 1938, o patético pessoal se apaga e se vê transparecer um drama que está ligado às estruturas mais gerais da ação humana, um trágico verdadeiro que é o da contingência histórica" (7, p. 157).

Nessa medida, a idéia que norteou as reflexões do filósofo em Sens et Non-Sens é reafirmada em Humanisme et Terreur, fundamentando sua interpretação dos processos de Moscou: a contingência é o fator essencial da história. Mais uma vez, a noção de necessidade histórica vai sendo diluída ao longo da análise merleau-pontyana até ser identificada com "linhas de fatos que se trata de prolongar para o futuro" (7, p. 159). Encontramos agora explicitada uma idéia que não era senão sugerida nos ensaios anteriores e que será mais tarde desenvolvida: "a história é terror porque há uma contingência" (7, p. 190). Lembremos mais uma passagem do livro: "A história é terror porque precisamos avançar não segundo uma linha reta, sempre fácil de traçar, mas nos reerguendo a cada momento sobre uma situação geral que muda, como um viajante que progrediria numa paisagem instável e modificada por seus próprios passos, onde o que era obstáculo pode tornar-se passagem e onde o caminho reto pode tornar-se sinuoso" (7, p. 194, Nota n). Os "jogos da história", seus "rodeios", - designados em "Autour du Marxisme" como "diversões" - tornam o processo histórico o lugar das "crueldades", "ironias" e "enigmas". "Há na história", escreve Merleau-Ponty, "uma espécie de malefício: ela solicita os homens, tenta-os, eles crêem caminhar no sentido dela, e súbito, ela se furta, o acontecimento muda, demonstra com fatos que outra coisa era possivel. Os homens que ela abandona e que não pensavam ser senão seus cúmplices encontram-se, súbito, os instigadores do crime que ela Ihes inspirou" (7, p. 129, nota o). Caprichosa, "diabólica" mesmo, conforme expressão do autor, a história possui dentro de si um "gênio maligno" capaz de "transformar a oposição em traição" (7, p. 163, Nota p). É essa concepção da história como terror que está subjacente à análise merleau-pontyana do "mistério" das confissões de Moscou.

Nesse sentido, nosso autor considera insuficientes as interpretações dos processos feitas tanto por Vichynski como por Trotsky, pois elas apagariam a "ambivalência da história" (7, p. 168). No primeiro caso, escreve o filósofo, "os acusados são pura e simplesmente culpados"; no segundo, "pura e simplesmente inocentes" (7, p. 167). Ambos deixariam de lado justamente o eixo central da análise de Merleau-Ponty: a ambigüidade da história faz dos homens políticos personagens de um drama. Podemos compreender melhor agora o recurso merleau-pontyano à figura do herói para explicar determinadas situações históricas: o homem político seria aquele que decide enfrentar o "gênio maligno" de uma história "diabólica". Seus conflitos, ou sua tragédia, seriam o outro aspecto da ambigüidade da história que se encontra, ela própria, tragicamente dilacerada entre suas "diversões" e suas "linhas de forças". Da mesma forma que em Sens et Non-Sens, nas análises de Humanisme et Terreur a dialética entre a lógica e a contingência históricas transforma-se em "jogos" no interior de uma história ambígua. O erro de Trotsky, afirma Merleau-Ponty, foi justamente ter acreditado demais na racionalidade do processo histórico ( donde o título do capítulo - "Le rationalisme de Trotsky "), perdendo, assim, a dimensão ambígua da história confirmada pelo exemplo do caso Bukharin (donde o título do capítulo - "A ambigüidade da história segundo Bukharin"). A análise trotskista não teria compreendido verdadeiramente as confissões de Moscou porque, expulsando a ambigüidade do processo histórico, não conseguiria dar conta dos momentos em que a história "deixa de.ser racional". Trotsky, na tentativa de preservar os "postulados racio-

Trans/Form/Ação, São Paulo, 9/10: 21-39, 1986/87. 
nalistas" da teoria da revolução permanente - a idéia de uma "história transparente ou sem espessura" - , acabaria, muitas vezes, negando o papel da contingência e do particular na história (7, p. 171, 177 e 178). Daí sua impossibilidade de compreender a situação histórica particular da sociedade soviética à época dos processos de Moscou.

Exemplo privilegiado das ambigüidades que caracterizam os textos merleau-pontyanos do pós-guerra, a análise dos processos de Moscou feita por Humanisme et Terreur nos desconcerta à primeira vista. Percebe-se ao longo de todo o livro oscilações e dificuldades que não se resolvem. No próprio fato de Merleau-Ponty criticar Trotsky porque este não teria dado conta da particularidade da situação da U. R. S. S. em 1938 já se pode ter um indício dessas dificuldades. Como procuramos assinalar, é justamente a particularidade daquele periodo histórico que se perde na análise do filósofo. Sem colocar qualquer problema relativo à conjuntura soviética, nosso autor destitui os processos de Moscou de seu conteúdo objetivo, transformando-os, para usarmos uma expressão com a qual Sartre designara a Resistência, numa "batalha cerimoniosa" (14, p. 662) - "cerimônia de linguagem" no caso da interpretação merleau-pontyana (Nota q). Em que medida, então, Merleau-Ponty pode criticar Trotsky em nome da particularidade da situação histórica em que ocorrem os processos de Moscou?

Todavia, as dificuldades que atravessam o livro são ainda maiores. Encontramos em Humanisme et Terreur afirmações que discrepam inteiramente do eixo diretor da análise do filósofo. "O marxismo - escreve por exemplo o autor - é, no essencial, essa idéia de que a história tem um sentido, - em outros termos, que ela é inteligivel e orientada (...)" (7, p. 236-237, Nota r). Ora, como já pudemos observar, é exatamente esse tipo de visão da história que Merleau-Ponty- ainda que pretendendo recorrer ao "bom método marxista" - questiona em todas as suas análises.

Ilustração da concepção merleau-pontyana da história e da política, o exame dos processos de Moscou feito pelo filósofo revela-nos, diferentemente da dialética marxista entre necessidade e contingência históricas, a idéia de uma história que é sobretudo indeterminação. Não obstante suas críticas posteriores a Sartre, Merleau-Ponty, ainda que de uma maneira escorregadia, desloca para o âmbito da história as indeterminações e ambigüidades da consciência. Lembremos ainda uma passagem de Humanisme et Terreur: "Vichynski se coloca nas coisas onde não há indeterminado. Queria apagar esse lugar de indeterminação, a consciência de Boukharin, onde havia coisas não sabidas, zonas de vazio, deixar ver as coisas que fez ou deixou de fazer" (7, p. 145, Nota s). A história na concepção merleau-pontyana, é ambígua exatamente por abrigar em seu centro os conflitos da consciência. Embora o filósofo tenha afirmado num dos ensaios de Sens et Non-Sens que "a política é impossivel na perspectiva da consciência" (6, p. 256), sua interpretação dos processos de Moscou não os estaria reduzindo, justamente, conforme expressão contida naqueles ensaios, a um "duelo de consciências"? Ou seja, estaríamos, nesse caso, diante de uma reflexão desencarnada na qual a história, sem conteúdo objetivo, torna-se o lugar onde se desenvolve a tragédia de heróis - personagem, ela própria, do drama da existência. Se em "Autour du Marxisme" o autor apresentou a história como um discurso, em Humanisme et Terreur esse discurso assume características mais definidas: é a narrativa da aventura de heróis. O curioso é que essa reflexão, distante de uma análise histórica concreta, ocorra exatamente no momento em que Merleau-Ponty pretendeu filiar-se ao marxismo - que não é, segundo o próprio autor, um "sistema de idéias", mas "uma leitura da história efetiva" (7, p. 144, Nota t). Convertendo os processos de Moscou num drama da consciência filosófica, ou, como tão bem afirmou Lefort, transformando os impasses do opositor em "tragédia intelectual" (Nota u), a análise merleau-pontyana não estaria, nesse momento, correndo o risco de converter a própria história em ato filosófico?

Podemos pois dizer que Humanisme et Terreur confirma e contradiz ao mesmo tempo as teses dos ensaios de Sens et Non-Sens. Se o autor pretende, também nesse livro, falar 
em nome da contingência e do particular na história, sua interpretação dos processos de Moscou anula, como vimos, justamente a particularidade daquela situação histórica. Nessa medida, acreditamos haver nas análises merleau-pontyanas do pós-guerra uma tensão interna constante entre seus propósitos e seus resultados. Donde as ambigüidades e oscilações presentes nos textos do período.

O sentido profundo de tais ambigüidades nós o encontramos no privilégio teórico que nosso autor pretende conceder ao marxismo, mas que suas análises, contudo, terminam por relativizar. Se o objetivo explícito de Merleau-Ponty é fazer a defesa da teoria de Marx, suas próprias reflexões sugerem que tal teoria constitui, no entanto, sobretudo um problema para o filósofo. Em Humanisme et Terreur, ainda mais significativamente que em Sens et Non-Sens, a oscilação entre fascínio e reserva diante do marxismo é constitutiva do pensamento do autor. Embora as análises de Merleau-Ponty terminem por destituir a história de toda objetividade, a idéia da síntese entre subjetividade e objetividade no processo histórico perpassa Humanisme et Terreur como um sonho que o filósofo acalenta e cuja realização lhe parece possivel através da teoria de Marx. Como conciliar, então, esse sonho com a perspectiva da "teoria existencial da história"? "O marxismo", escreve o autor, "não é nem a negação da subjetividade e da atividade humana, nem o materialismo cientificista de onde Roubachof partiu, - ele é sobretudo uma teoria da subjetividade concreta e da atividade concreta, isto é, comprometidas na situação histórica" (7, p. 107, Nota v). Essa "teoria da subjetividade concreta", no entanto, é entendida por Merleau-Ponty como uma percepção da história que faz aparecer a cada momento as linhas de força e os vetores do presente" (7, p. 198). Na análise merleau-pontyana a "dialética do subjetivo e do objetivo" - expressão de "nosso enraizamento na verdade" - é descrita como "comprometimento de cada consciência com as outras numa história comum" (7, p. 196). Percebe-se, pois, o deslizamento do sentido: da idéia de "dialética do subjetivo e do objetivo" passamos, sem distinção, à idéia, presente desde o começo do livro, de "dialética da intersubjetividade concreta", ou, mais precisamente, "dialética" das "relações entre o eu e o outro" (7, p. 123).

É bem verdade que Humanisme et Terreur procura apresentar o marxismo como uma teoria da revolução do proletariado. É através da "condição proletária", afirma MerleauPonty, que "o marxismo quer destruir a alternativa da política subjetiva e da política objetiva" (7, p. 215). A análise merleau-pontyana parece, pois, recuperar aqui o ponto de vista da teoria marxista clássica. Esta teoria, escreve ainda o filósofo, "outorga ao proletariado uma missão, mas não providencial, histórica, e isso quer dizer que o proletariado, considerando o seu papel na constelação histórica dada, vai em direção a um reconhecimento do homem pelo homem" (7, p. 216). Nessa medida, "a teoria do proletariado não é no marxismo um anexo ou um apêndice. É verdadeiramente o centro da doutrina" (7, p. 217). É por esta razão que, "se quisermos compreender a violência marxista e fazer o balanço do comunismo de hoje, precisamos voltar à teoria do proletariado" (7, p. 218). Merleau-Ponty, reportando-se a Marx e a Lenin, faz, então, uma exposição detalhada sobre o caráter historicamente revolucionário da classe operária.

Ao longo dessa exposição percebe-se que o objetivo do filósofo é contrapor a perspectiva marxista clássica às esquematizações presentes no comunismo atual. No entanto, percebe-se também que a análise merleau-pontyana não aponta para a pretendida "volta à teoria do proletariado". Se o marxismo clássico é contraposto ao atual é, sem dúvida, para lamentar o que se perdeu, mas não para tentar recuperá-lo. Pelo contrário, embora procure descrever, conforme Marx, a teoria da revolução do proletariado, Merleau-Ponty vai questioná-la em seguida. Ou melhor, na própria apresentação desta teoria já se esboçam as desconfianças de nosso autor para com ela.

É assim que no decorrer da exposição, cujo objetivo é fazer o elogio da teoria do proletariado, deparamo-nos com a seguinte questão apresentada numa nota: "a questão é saber se (...) temos ainda a menor razão para acreditar numa lógica da história no mo-

Trans/Form/Ação, São Paulo, 9/10: 21-39, 1986/87. 
mento em que ela rejeita o regulador da dialética: o proletariado mundial" (7, p. 229). A questão, ainda que colocada em nota, não é marginal ao texto: embora de maneira quase sempre implícita, ela norteia as reflexões do autor ao longo do livro e prepara as hipóteses pessimistas sobre a teoria da revolução que encontramos formuladas no final. Ora, se o filósofo afirma que a teoria do proletariado é o essencial do marxismo e se, hoje, a história "rejeita" o proletariado, não é o marxismo na sua totalidade que está posto em questão? Donde o diagnóstico, apresentado no Prefácio, de uma "crise da dialética marxista" (7, p. 60). Merleau-Ponty considera que a história não trilhou o caminho previsto pelo marxismo e, nessa medida, adverte: "A dialética é doravante ilegível" (7, p. 253). Procurando "olhar realisticamente" seu tempo, "e não através de lembranças e sonhos", o filósofo constata e lamenta a degenerescência do marxismo: "Talvez haja ainda uma dialética, mas do ponto de vista de um Deus que conheceria a História Universal" (7, p. 254). Porém, imediatamente, prenunciando Les Aventures de la Dialectique, escreve que a "revisão" do marxismo clássico talvez tenha sido "inevitável" (7, p. 254).

Compreende-se melhor agora porque Merleau-Ponty afirma que o livro de Koestler "coloca o problema de nosso tempo". Assim como ocorrera no diálogo com Maulnier em "Autour du Marxisme", as reservas de Koestler a respeito do marxismo são também compartilhadas por nosso autor. Embora o filósofo se empenhe em criticar o mecanicismo de Koestler, ressalta, por outro lado, que sua crítica ao marxismo esbarra em problemas reais. Mais uma vez, a análise merleau-pontyana oscila: se, contra Koestler, Merleau-Ponty procura mostrar que a história - por ser ao mesmo tempo contingente e necessária - é paradoxal, esse paradoxo, no entanto, é muitas vezes deslocado para o interior da teoria marxista. Ou seja, a dificuldade - como já mostravam os primeiros escritos do autor - estaria na teoria que pensa a história como contingente e necessária ao mesmo tempo. Daí a necessidade (apenas sugerida) de repensar o esquema marxista clássico.

Visto que a revolução não se deu conforme fora concebida pela teoria da revolução, pondera Merleau-Ponty, é preciso então reconhecer que o marxismo foi "incapaz de dar forma à história mundial" (7, p. 266). As questões formuladas na segunda parte de $\mathrm{Hu}$ manisme et Terreur evidenciam as dificuldades encontradas pelo autor em sua pretendida filiação ao marxismo: "com o declínio da ideologia e da prática proletárias aparece o verdadeiro problema, em torno do qual Koestler gira sem o formular jamais: a Revolução pode sair do terror? Há uma missão histórica do proletariado, ao mesmo tempo força motriz da sociedade nova e portadora dos valores da humanidade? Ou, ao contrário, a Revolução é inevitavelmente um empreendimento voluntário, conduzido por chefes e por uma categoria dirigente, sofrido pelos outros? (7, p. 261). O ceticismo a respeito da revolução que transparece na última parte do livro é, ao mesmo tempo, um ceticismo a respeito da teoria da revolução. Ainda que não inteiramente explicitada, é possível entrever a hipótese que direciona as reflexões finais do filósofo: talvez a teoria que concebeu a história como o caminho da revolução faça parte, ela também, das ilusões para sempre perdidas junto com o espírito de 1917. Donde a necessidade de se "fixar um prazo para a prova histórica do marxismo": "Não se pode recuar indefinidamente o momento em que se deverá decidir se a filosofia proletária da história é ou não aceita pela história. O mundo em que vivemos é a esse respeito ambíguo" (7, p. 262). A "história em suspenso", conforme a já mencionada expressão do autor no início do livro, põe também em suspenso o marxismo como teoria da revolução.

Merleau-Ponty vai buscar em Trotsky a justificativa para a fixação de um prazo para que a história decida sobre a verdade do marxismo. Até um revolucionário de 17 da qualidade de Trotsky, afirma o filósofo, "preso à filosofia proletária de Marx a ponto de deduzir dela diretamente sua tática, (...) admitiu entretanto nos seus últimos anos que, (...) se o marxismo é verdadeiro, ele deve no final de contas aparecer no acontecimento" (7, p. 263). Recuperando as questões pessimistas que Trotsky formulou sobre os rumos da história, e afastando-se do otimismo com que procurou responder a tais questões - "nos 
anos da reação mundial devemos partir das possibilidades que o proletariado russo revelou em 1917" - (Nota w), Merleau-Ponty já considera a possibilidade de um fracasso definitivo da revolução do proletariado e da teoria desta revolução. Nesse sentido, via Trotsky, Humanisme et Terreur apresenta a hipótese que Les Aventures de la Dialectique pretende confirmar: se o proletariado foi incapaz de cumprir sua missão histórica, a teoria da revolução terá sido, afinal, uma "utopia" (7, p. 263-264). Em algumas passagens, a interrogação já é quase afirmação: "Talvez nenhum proletariado venha a exercer a função histórica que o esquema marxista reconhece ao proletariado. Talvez a classe universal não se revele jamais..." (7, p. 269). Embora possamos vislumbrar aqui o fim do attentisme marxiste, o fascínio do filósofo pelo marxismo faz com que ele procure ainda neutralizar as reservas que transparecem em suas análises, reabrindo, assim, o problema: "Uma coisa é reconhecer que a história não tomou a forma prevista pelo marxismo, e outra é declará-lo ultrapassado e procurar a solução do problema humano através de caminhos que ele perfeitamente mostrou que reconduzem aos conflitos eternos" (7, p. 259). Ou então: "O declínio do humanismo proletário não é uma experiência crucial que anula o marxismo inteiro" (7, p. 265-266). Essa certeza, no entanto, as próprias reflexões do autor se encarregam de desfazer.

Percebe-se, pois, nos textos de Merleau-Ponty do pós-guerra uma espécie de círculo vicioso que se repete sempre e do qual o filósofo não consegue sair: seu propósito de fazer a defesa do marxismo é constantemente negado por suas análises. Questionado de ponta a ponta pelas reflexões do autor, o marxismo é resgatado, todavia, numa ou noutra passagem, quase como uma profissão de fé: "O marxismo não é uma filosofia da história, é a filosofia da história, e renunciar a ele é fazer uma cruz sobre a Razão histórica. Após o que, não há senão fantasias ou aventuras" (7, p. 266). Ora, toda a análise de Merleau-Ponty, como procuramos mostrar, questionando a idéia de uma razão histórica, apresenta a história justamente como uma aventura. Contradições que atravessam os textos daquele período? Acreditamos que tais oscilações e ambigüidades constituem, sobretudo, a expressão do difícil diálogo do filósofo com uma teoria que, naquele momento, ele não pretende ultrapassar, mas à qual tampouco pode se filiar inteiramente. "O dilema da consciência e da política, escreveu Merleau-Ponty no prefácio de Humanisme et Terreur, - aderir ou renegar, ser fiel ou ser lúcido - , impõe uma dessas escolhas lancinantes (...." (7, p. 60). É exatamente tal escolha que o próprio autor se recusa a fazer. $O$ conflito está, portanto, instaurado no coração de uma filosofia que procura, sem aderir mas também sem renegar, aproximar-se do marxismo até onde seus pressupostos teóricos permitem. Na impossibilidade de resolver os impasses decorrentes dessa tentativa de aproximação - e na espera (e esperança) de que "uma nova movimentação da história" possa, talvez, responder às questões formuladas - , o filósofo lança para a história a decisão sobre a verdade do marxismo (Nota $x$ ).

Durante a espera, e na dúvida se a teoria da revolução será, finalmente, confirmada pelo processo histórico, Merleau-Ponty encontra uma solução provisória. Mesmo se o marxismo for definitivamente desmentido como teoria da revolução, afirma o filósofo, é preciso salvá-lo como "crítica do mundo existente e dos outros humanismos" (7, p. 266). Mais tarde, fazendo um balanço crítico do período de attentisme marxiste, o próprio autor procura definir sua relação com o marxismo naquela época: tratava-se de "dar-l'he razão naquilo que ele nega e de considerá-lo errado naquilo que afirma" (11, p. 338). Donde a grande dificuldade da tentativa merleau-pontyana de aproximação da teoria de Marx: o marxismo foi aceito pelo filósofo como crítica da desumanização do capitalismo, como "crítica moral", mas questionado em sua concepção da história e da revolução. Essa dificuldade - e as ambigüidades decorrentes dela - só se desfaz quando Merleau-Ponty, à época de Les Aventures de la Dialectique, passa a recusar o marxismo na sua totalidade.

Esse desfecho dos anos 50, no entanto, já se anunciava na própria precariedade da solução encontrada pelo filósofo no pós-guerra. O equilíbrio frágil que tentou manter entre as duas perspectivas antagônicas presentes em seus textos - "aderir ou renegar" -

Trans/Form/Ação, São Paulo, 9/10: 21-39, 1986/87. 
e a tensão interna que daí resulta levam o pensamento merleau-pontyano a caminhar rumo a uma tentativa de resolução das oscilações que o dilaceram. Validar o marxismo como denúncia do capitalismo e pôr em suspenso sua teoria da revolução era uma solução por demais precária para ser mantida. Como separar a teoria da revolução da teoria do proletariado - o "centro" do marxismo, segundo Merleau-Ponty - sem quebrar a unidade estabelecida por Marx entre a teoria e a prática? No entanto, a concepção merleaupontyana da história como o lugar da ambigüidade e da indeterminação coloca dificuldades intransponiveis na tentativa de conciliação com uma teoria que procurou, justamente, descrever a necessidade histórica do surgimento da "sociedade nova", "gerada nas entranhas da velha" (5, p. 639). A própria visão que Merleau-Ponty tem do processo histórico já indica portanto que, desfeito o equilíbrio provisório estabelecido em suas análises do pós-guerra, é a recusa do marxismo que deve prevalecer sobre a tentativa de adesão.

Nas páginas finais de Humanisme et Terreur, retomando, de certa maneira, a idéia presente no início do livro de que "o reino de uma razão universal é problemático", pois o homem, "para falar como Sartre, (...) está lançado numa aventura da qual a saída feliz não tem garantia", (7, p. 73), Merleau-Ponty recupera explicitamente a perspectiva da filosofia "existencialista" e indica que o marxismo não dá conta das questões colocadas pela situação histórica presente. Os "desvios do presente são tais" (7, p. 245) que o marxismo clássico não pode mais descrevê-lo: "Assim, os principais papéis da história são desempenhados por personagens nos quais dificilmente se reconheceria o "capitalismo" e o "proletariado" da descrição clássica, e cuja ação histórica permanece ambígua" (7, p. 298, Nota y). A análise merleau-pontyana finaliza descrevendo o "mundo humano" como um "sistema aberto ou inacabado" (7, p. 309) e já deixa entrever a idéia de que ele não pode ser reduzido a um único sentido pois tem várias "faces" (Nota z). Mais do que isso: a história - escreve Merleau-Ponty sem, contudo, desenvolver a hipótese - talvez seja "irracional" (7, p. 305). Embora tenha apresentado o marxismo como um "ensaio de solução do problema humano" (7, p. 295), o filósofo sugere na conclusão do livro que a história, diferentemente dos "problemas de geometria onde há desconhecido, mas não indeterminado", não é um problema que comporte "uma solução" (7, p. 306, 307). Mas aqui é a própria perspectiva de Humanisme et Terreur que já foge do horizonte, cedendo lugar à perspectiva das Aventures de la Dialectique onde, fazendo suas as reflexões de Weber, Merleau-Ponty escreve justamente o seguinte: "Uma solução histórica do problema humano, um fim da história, só seria concebível se a humanidade fosse uma coisa a ser conhecida, se nela o conhecimento esgotasse o ser, se pudesse chegar a um estado que contivesse realmente tudo que ela foi e tudo que poderá ser" (11, p. 37).

Esboçando, pois, as idéias centrais que vão determinar posteriormente a recusa definitiva dos fundamentos da teoria da revolução, Humanisme et Terreur nos ajuda a compreender o sentido do itinerário filosófico de Merleau-Ponty. Justamente por ter representado o momento maior da tentativa merleau-pontyana de aproximação do marxismo, este livro põe a nu os limites desta aproximação. Seu final, indicando que a teoria marxișta não dá conta da situação histórica presente, já prepara o fim do attentisme marxiste. “É verdade que um poder revolucionário nega o indivíduo, seus julgamentos, suas intenções, suas honras e até sua honra revolucionária?" (7, p. 109) - perguntara MerleauPonty refletindo sobre o livro de Koestler. Se em Humanisme et Terreur ainda não é possível encontrar uma resposta clara para esta questão, mais tarde, resolvidas as oscilações, percebe-se que os fundamentos da resposta afinal explicitada já estavam presentes naquele período. Questionando a idéia de uma lógica imanente ao movimento histórico e a luta de classes como "princípio geral da história", acentuando o aspecto ambíguo e dramático da história e a importância que nela exercem os acidentes e a livre escolha dos homens, as análises merleau-pontyanas do pós-guerra já permitem compreender porque conforme acreditamos, o filósofo vai buscar posteriormente no "liberalismo heróico" de Weber uma alternativa para a superação do marxismo. Nessa medida, as próprias in-

Trans/Form/Ação, São Paulo, 9/10: 21-39, 1986/87. 
terrogações de Merleau-Ponty naquele período de attentisme marxiste, sugerindo as respostas que aos poucos se delineiam, são sinais indicadores de que o caminho por ele percorrido encerra um sentido e talvez tenha sido necessário.

\section{NOTAS}

a) No prefácio de Sens et Non-Sens (1948), Merleau-Ponty afirma que os ensaios "Autour du Marxisme" e "Pour la Vérité" exprimem a esperança que no dia seguinte à guerra ainda era possivel depositar na "política marxista" e nos rumos do processo histórico (cf. 6, p. 9-10).

b) Merleau-Ponty analisa particularmente os seguintes livros de T. Maulnier: Violence et Conscience e Au-delà du Nationalisme.

c) Nesse sentido, lembremos uma passagem do capítulo sobre Weber ("La crise de l'entendement") de Les Aventures de la Dialectique: "A história comporta fatos dialéticos, significações esboçadas não é um raciocínio seqüente. Como um interlocutor desatento, deixa desviar o debate, esquece pelo caminho os dados do problema." (11, p. 40)

d) Cabe ressaltar que a Revolução Francesa, a Revolução Russa e a Resistência significam para Merleau-Ponty momentos privilegiados - momentos de lampejo - em que a história se tornou inteligivel.

e) A expressão encontra-se na Phénoménologie de la Perception (cf. 10, p. 201). A partir dos anos 50, Sartre vai procurar desenvolver algumas teses que Merleau-Ponty defendera no pós-guerra e abandonara posteriormente. Nesse sentido, na Questão de Método, o filósofo afirma que o existencialismo está em desacordo apenas com um certo "determinismo mecanicista" e não com a teoria marxista da história. Como o marxismo, escreve o autor, também o existencialismo tenta um "deciframento dialético da história". No entanto, ele o faz "a partir da existência". Seu propósito é "reintroduzir a insuperável singularidade da aventura humana". Posto de lado o "determinismo mecanicista", Sartre considera que esse propósito pode perfeitamente ser conciliado com o marxismo, ou melhor, pode ser desenvolvido "no seio do próprio marxismo" (17, p. 194-195). A trajetória dos dois filósofos é curiosa: Sartre procura se aproximar da teoria de Marx justamente no momento em que Merleau-Ponty rompe definitivamente com ela.

f) No Epílogo das Aventures de la Dialectique (11, p. 333) Merleau-Ponty escreve: "Nous avions essayé au lendemain de la guerre de formuler une attitude d'attentisme marxiste". Na tradução de textos de Merleau-Ponty feita por Marilena Chauí para a Coleção Os Pensadores (que muito nos auxiliou e que utilizamos com freqüência) a expressão attentisme marxiste foi traduzida como "contemporização marxista" (Pensadores, Abril, 1975, p. 255). Preferimos, no entanto, traduzir a expressão por "temporização marxista", pois julgamos fundamental enfatizar a idéia de espera. Acreditamos que contemporizar passa mais o sentido de transigir do que de adiar. Existe, é claro, uma atitude de transigência de Merleau-Ponty a respeito do marxismo. Todavia, trata-se sobretudo de adiar uma decisão.

g) Apenas chamamos atenção aqui para a expressão "política eficaz" utilizada por Merleau-Ponty na passagem que acabamos de mencionar. A idéia de eficácia é fundamental para entender a justificativa merleau-pontyana do stalinismo (a qual não podemos examinar nos limites deste artigo).

Trans/Form/Ação, São Paulo, 9/10: 21-39, 1986/87. 
h) Em Les Aventures de la Dialectique, Merleau-Ponty vai falar num "descarrilamento da dialética" (11, p. 129).

i) A maior parte dos capítulos que compõem Humanisme et Terreur (cuja primeira edição data de novembro de 1947) já fora publicada em Les Temps Modernes no final de 1946 e início de 1947.

j) Lefort escreve o seguinte: “(...) tanto na fiç̧ão de Le Zéro et l'Infinit como na interpretação de Humanisme et Terreur, o contexto sócio-histórico é apagado no curso do exame dos processos" (3, p. 153). É interessante observar que Lefort critica Humanisme et Terreur em nome das Aventures de la Dialectique. O fato de Merleau-Ponty ter deixado de lado o "contexto sócio-histórico" dos processos de Moscou não constitui (salvo nas passagens de Un Homme en Trop onde aborda o assunto) o eixo principal da crítica que Lefort endereça a Humanisme et Terreur. Tanto em Sur une Colonne Absente como na "Introduction" a Humanisme et Terreur, suas restrições ao livro coincidem com as do próprio Merleau-Ponty (nas Aventures de la Dialectique) e podem ser assim resumidas: a atitude de transigência do autor a respeito da teoria marxista o impede de criticar radicalmente a "estranhas conseqüências" (a expressão é de Lefort) desta teoria.

k) O tema do heroísmo percorre toda a obra merleau-pontyana. A esse respeito ver particularmente o último capítulo da Phénoménologie de la Perception (10) e os ensaios "La Guerre a eu lieu" e "Le herós, I'homme" (6).

1) Ao longo de todo o livro podemos perceber essa analogia entre a situação soviética (embora não haja análise daquela conjuntura) e a situação da França durante a ocupação. O momento histórico vivido por Bukharin é também compreendido por Merleau-Ponty como uma situação limite (a história "em suspenso") que põe o homem diante de uma "decisão fundamental". Nesse aspecto, julgamos correta a crítica que Lukács endereça aos "existencialistas" quando chama atenção para os perigos (o surgimento de "mitos") de uma "generalização teórica" dessa "nostalgia da simplicidade poética do tempo da Resistência" (4, p. 62). Embora aponte problemas reais, o livro de Lukács, no afã de fazer a defesa da ortodoxia soviética ("Merleau-Ponty evoca os processos de Moscou; ora, o que foram esses processos, em suma, senão a revelação da essência mesma do trotskismo, da traição em relação à revolução, uma traição que ia até a espionagem?"' - p. 201), termina por esquematizar o pensamento dos "existencialistas" franceses.

m) No prefácio de Signes, Merleau-Ponty - de maneira, agora, não mais interrogativa - escreve: "A política é a moderna tragédia" (8, p. 11).

n) Caberia lembrar aqui uma passagem de V. Descombes: “Kojève lega a seus ouvintes uma concepção terrorista da história. Reencontra-se esse tema do terror em todos os debates que se sucedem até nossos dias: no título do livro que escreve Merleau-Ponty em 1947 (Humanisme et Terreur) : ( ... ) i nas análises consagradas por Sartre à revolução francesa em sua Critique de la Raison Dialectique (tema da "fraternidade-terror"), assim como em suas apologias da violência." (2, p. 27).

o) É interessante recordar aqui uma afirmação de Merleau-Ponty nos Résumes de Cours: "Weber faz da história uma espécie de malefício" (12, p. 48). Nosso autor escreve também o seguinte: "Max Weber privilegia a contingência radical e a infinitude do fato histórico" (12, p. 47). Lembremos uma passagem do próprio Weber descartando a idéia de necessidade histórica: "Devemos evidentemente libertar-nos da idéia de que é possivel interpretar a Reforma como "conseqüência histórica necessária" de certas mudanças econômicas"(18, p. 61).

p) No prefácio de Signes, retomando e desenvolvendo essa concepção trágica da história, MerleauPonty escreve que o "fluxo da história" é uma "maré de angústia" (8, p. 38).

Trans/Form/Ação, São Paulo, 9/10: 21-39, 1986/87. 
q) É uma constante nos textos políticos merleau-pontyanos esse tipo de interpretação dos acontecimentos sociais que termina por despojá-los de toda objetividade. O social aparece nas análises do filósofo como rapports des consciences. Em Sartre, torna-se ainda mais acentuada a ausência de uma análise concreta dos acontecimentos sociais examinados pelo autor. Nesse sentido, no artigo "Paris sous l'Occupation", Sartre afirma que não é suficiente determinar "I'aire sociale de la collaboration", é preciso fazer uma psicologia do Colaborador $(15$, p. 50). A análise sartreana se detém nos sentimentos que a ocupação provocou nos franceses, eliminando, assim, todo o conteúdo político da Colaboração e da Resistência. Em nenhum momento do texto o autor procura examinar a conjuntura social e política da França naquela situação histórica determinada. É interessante pensar até que ponto os "existencialistas" franceses, embora fazendo a crítica daquilo que Simone de Beauvoir chamou de "velho idealismo tradicional dos universitários franceses (um deles escrevia a respeito da guerra de 1914 que ela era "a luta de Descartes contra Kant")", não teriam pago um tributo a essa tradição. (Simone de Beauvoir, "Merleau-Ponty et le PseudoSartrisme", Privilèges, Gallimard, 1955, p. 269).

r) O filósofo escreve também o seguinte: "A revolução marxista não é irracional: é o prolongamento e a conclusão tógica do presente" (7, p. 124). Se Merleau-Ponty pretende falar em nome do marxismo, em que medida, então, é possivel conciliar essa idéia da revolução como "o prolongamento e a conclusão lógica do presente" com a idéia de que a história é o lugar do "equívoco perpétuo" e da ambigüidade?

s) Nas Aventures de la Dialectique Merleau-Ponty critica Marx porque este teria colocado a dialética nas "coisas", ou seja, nas condições objetivas. Se a história é o domínio da indeterminação, seu motor não pode estar nas "coisas", pois nelas "não há indeterminado". No entanto, é ainda nas páginas de Les Aventures de la Dialectique que encontramos a seguinte crítica a Sartre: "É o contato teórico e prático com a história que ele recusa, decidindo não mais buscar nela senão a iluminura de um drama cujos personagens - O Eu e o Outro - são definidos a priori pela via da reflexão" (11, p. 284). Nesse sentido, poderíamos dizer que as análises merleau-pontyanas acabariam muitas vezes aproximąrićo-se daquilo que seu próprio autor critica em Sartre.

t) Mais tarde, sobretudo no Prefácio de Signes, o filósofo passa a considerar o marxismo justamente como um "sistema de idéias".

u) Lefort escreve o seguinte: "Tanto para Koestler como para Merleau-Ponty, o vínculo do opositor ao Partido procede da representação deste último como peça mestra da teoria. Em suma, o opositor não pode se opor verdadeiramente porque sacrificaria, assumindo o risco de sua exclusão, a idéia de que o Partido dirige o processo revolucionário. Tal é, pois, sua tragédia: intelectual" ( 3 , p. 153 - 154).

v) O sonho com uma síntese entre subjetividade e objetividade na história aparece também claramente no texto de Sartre "Faux Savants ou Faux Lièvres?" (Prefácio escrito em 1950 para o livro de Louis Dalmas, Le Communisme Yougoslave depuis la rupture avec Moscou). Retomando explicitamente as reflexões de Merleau-Ponty em Humanisme et Terreur, Sartre exalta o socialismo iugoslavo como uma experiência que introduziu a subjetividade na história: "O titismo tem para nós uma importância excepcional porque encerra em si a subjetividade" (16, p. 19). Nesse sentido, a questão que norteia o texto é a seguinte: como pensar a história sem privilegiar a objetividade em detrimento da subjetividade? Sartre encontra na experiência iugoslava elementos para suas reflexões sobre a história. No entanto, tal como ocorre com a análise merleau-pontyana dos processos de Moscou, a situação histórica da Yugoslávia, destituída de toda objetividade, aparece somente como pano de fundo das reflexões do autor sobre o papel da liberdade e da subjetividade no processo histórico. A síntese entre o objetivo e o subjetivo na história torna-se, nessa medida, apenas uma idéia exterior à análise de Sartre.

Trans/Form/Ação, São Paulo, 9/10: 21-39, 1986/87. 
w) Trotsky, L., "The USSR in war", artigo citado por Merleau-Ponty (cf. 8, p. 326).

x) Mais tarde (no prefácio de Signes) esse recurso ao julgamento da história será posto de lado.

y) Em "Faux Savants ou Faux Lièvres", Sartre também procura mostrar que o marxismo clássico não dá conta da situação histórica presente (no caso, a experiência do socialismo iugoslavo) e, nessa medida, indica a necessidade de repensar a teoria marxista: "A pressão das circunstâncias objetivas e as contradições do próprio objetivismo levaram-nos, contra a vontade, a revalorizar a subjetividade; mas, por sua vez, esta revalorização exige uma modificação teórica; é necessário refletir de novo sobre o marxismo, é necessário refletir de novo sobre o homem" (16, p. 45).

z) Nas Aventures de la Dialectique, Merleau-Ponty considera um dos mais corretos ensinamentos de Weber a idéia de que "a história tem não um sentido como o rio, mas sentido" (11, p. 46). No Éloge de la Philosophie já se pode sentir essa influência weberiana: "A história não tem sentido se seu sentido é compreendido como o de um rio que corre sob a ação de causas poderosas em direção a um oceano onde desaparece" $(13$, p. 61).

MENDONÇA, C. D. - Marxism and philosophy: some considerations on Merleau-Pontyan post-war political texts. Trans/Form/Ação, São Paulo, 9/10 : 21-39, 1986/87.

ABSTRACT: Merleau-Ponty's attempt to approach Marxism, undertaken in the post-war years, is passed through by continuous ambiguity. Notwithstanding the philosopher's purpose of joining the Marxist theory, his political analysis are far from his intentions. Conceiving history as an "adventure" which escapes any rational scheme, Merleau-Ponty questions, since his first writings, Marxist dialectics between logic and contingency in history. The inner tension that lacerates the author's texts during the 40's, proclaiming (and preparing) the refusal of the theory of revolution, which would later appear in The Adventures of the Dialectics, permits us to inquire wheter the dénouement of the 50's would not have been - instead of a cutting in the heart of the work - the necessary result of this problematic attempt to approach Marxism, departing from categories which are alien to it (suitable to philosophies of existence and to phenomenology).

KEY-WORDS: Marxism; existentialism; attentisme marxiste; theory of history; logic and contingency in history; revolution; Weberian "heroic liberalism". 


\section{REFERÊNCIAS BIBLIOGRÁFICAS}

1. ARON, R. - La Sociologie Allemande Contemporaine. Paris, Presses Universitaires de France, 1981.

2. DESCOMBES, V. - Le Même et L'Autre. Quarente-cinq ans de philosophie française (1933-1978). Paris, Minuit, 1979.

3. LEFORT, C. - Un Homme en Trop - Réflexions sur "L'Archipel du Goulag". Paris, Seuil, 1976.

4. LUKÁCS, G. - Existencialismo ou Marxismo. São Paulo, Ciências Humanas, 1979.

5. MARX, K. - El Capital. México, Fondo de Cultura Econòmica, 1973. v. I.

6. MERLEAU-PONTY, M. - Sens et Non-Sens. Paris, Nagel, 1966.

7. MERLEAU-PONTY, M. - Humanisme et Terreur - Essai sur le problème communiste. Paris, Gallimard, 1980.

8. MERLEAU-PONTY, M. - Signes. Paris, Gallimard, 1960.

9. MERLEAU-PONTY, M. - A linguagem indireta e as vozes do silêncio. São Paulo, Abril, 1975. (Pensadores).

10. MERLEAU-PONTY, M. - Phénoménologie de la Perception. Paris, Gallimard, 1945.

11. MERLEAU-PONTY, M. - Les aventures dela dialectique. Paris, Gallimard, 1955.

12. MERLEAU-PONTY, M. - Résumés de Cours. Paris, Gallimard, 1968.

13. MERLEAU-PONTY, M. - Éloge de la Philosophie. Paris, Gallimard, 1960.

14. SARTRE, J.- P. - La Libération de Paris: une semaine d'apocalypse. In: CONTAT, M. \& RYBALKA, M. - Les écrits de Sartre. Paris, Gallimard, 1970.

15. SARTRE, J.- P. - Paris sous I'occupation. In:— Situations III. Paris, Gallimard, 1949.

16. SARTRE, J.- P. - Falsos sábios ou falsas lebres? In: Situaçōes VI. Problemas do marxismo. Póvoa do Varzim (Portugal), Publicações Europa-América, 1975.

17. SARTRE, J.- P. - Questão de Método. São Paulo, abril, 1973. (Pensadores).

18. WEBER, M. - A ética protestante e o espírito do capitalismo. São Paulo, Pioneira, 1967.

Trans/Form/Ação, São Paulo, 9/10: 21-39, 1986/87. 